UDC 327.2

Submitted: 30.11 .2016

LBC 66.4(Иран)

Accepted: 02.04.2017

\title{
FROM THE HISTORY OF THE LOAN AND ACCOUNT BANK OF PERSIA (FROM THE RUSSIAN ARCHIVES)
}

\author{
Irina K. Pavlova \\ Saint Petersburg State University of Industrial Technologies and Design, \\ Saint Petersburg, Russian Federation
}

\begin{abstract}
The article analyzes new Russian archival materials related to the activities of the Loan and Account Bank of Persia from the late nineteenth century to the early twentieth century. The article illustrates how the Bank through its various activities, turned into one of the main agents of Russian state interest in Persia during that period. The performance of the Bank has been elucidated in the works of Russian and foreign researchers encompassing various aspects of the Bank's activities. This article, however, is based on the previously unused materials from the Russian State Historical Archive (RGIA, St. Petersburg) and the Archive of Foreign Policy of the Russian Empire (AVPRI, Moscow). Among the new materials introduced and employed in this article, two documents are of an exceptional importance: "Case of rewarding Persian subjects with Russian orders and medals" and "Case of purchasing a movie theatre". These documents confirm that the Bank's works in Persian were multi-faceted. Many merchants were involved in commercial relations with the Bank. At the same time, some of them were informants of the Bank and helped the Russians to monitor the situation in Persia. On avenue used by the Board in order to maintain amiable relationships with Shah and His immediate circle was to bestow fascinating gifts on them.

Key words: Loan and Account Bank, archival documents, Russia, Persia (Iran), international relations.

Citation. Pavlova I.K. Iz istorii deyatelnosti Uchetno-ssudnogo banka Persii (po materialam russkih arhivov) [From the history of the Loan and account bank of Persia (from the Russian archives)]. Vestnik Volgogradskogo gosudarstvennogo universiteta. Seriya 4, Istoriya. Regionovedenie. Mezhdunarodnye otnosheniya [Science Journal of VolSU. History. Area Studies. International Relations], 2017, vol. 22, no. 2, pp. 47-60. (in Russian).

УДК 327.2

Дата поступления статьи: 30.11.2016

ББК 66.4(Иран)

Дата принятия статьи: 02.04.2017
\end{abstract}

\section{ИЗ ИСТОРИИ ДЕЯТЕЛЬНОСТИ УЧЕТНО-ССУДНОГО БАНКА ПЕРСИИ (ПО МАТЕРИАЛАМ РУССКИХ АРХИВОВ)}

\author{
Ирина Константиновна Павлова \\ Санкт-Петербургский государственный университет промышленных технологий и дизайна, \\ г. Санкт-Петербург, Российская Федерация
}

\footnotetext{
Аннотация. В основу данной статьи легли неопубликованные и до сих пор мало известные исследователям материалы Российского государственного исторического архива (РГИА, Санкт-Петербург) и Архива внешней политики Российской империи (АВПРИ, Москва), касающиеся разнообразной деятельности Учетно-ссудного банка Персии в конце XIX - начале XX века. В частности, в статье подробно рассматриваются два неопубликованных документа «Дело о награждении персидских подданных орденами и медалями» и «Дело о покупке кинематографа». Обнаруженные нами архивные документы банка подтверждают его раз․ ностороннюю деятельность в Персии и являются важными дополнительными сведениями к уже известным 尺े фактам о функциях Учетно-ссудного банка Персии.

Ключевые слова: Учетно-ссудный банк, архивные документы, Россия, Персия (Иран), международные отношения.

Цитирование. Павлова, И. К. Из истории деятельности Учетно-ссудного банка Персии (по материалам русских архивов) / И. К. Павлова // Вестник Волгоградского государственного университета. Серия 4, История. Регионоведение. Международные отношения. - 2017. - Т. 22, № 2. - С. 47-60.
} 
I

Развитие капитализма в России во второй половине XIX в. и расширение ее геополитических интересов в этот период повлекли за собой появление новых форм взаимоотношений Царского правительства со странами Востока, в частности с соседней Персией ${ }^{1}$. Активизация России в Персии, с которой она непосредственно имела общую границу, была вызвана ее противостоянием с Англией в этом регионе. Как известно, в 1889 г. английский барон Юлиус Рейтер открыл в Персии Шахиншахский (или Императорский) банк, представлявший интересы своей страны в Персии $[3 ; 25 ; 26]$. В ответ на это, для усиления своих позиций в Персии и главным образом в северных провинциях этой страны, Царское правительство предоставило возможность частным российским предпринимателям получать концессии у шаха и разрешало им вкладывать свои капиталы в экономику персов: рыбный промысел, создание торговых предприятий, сторительство порта Энзели, обустройство дорог и др.

Однако довольно скоро эти частные компании попали под контроль государственного капитала. Официально они оставались зарегистрированы как частные, но практически оказались в руках государственного капитала. Это давало возможность Российскому государству юридически находиться вне сферы вмешательства во внутренние дела Персии.

Свидетельством этому могут служить архивные данные о создании Учетно-ссудного банка Персии, который получил свое развитие на основе Ссудного общества Персии, частного предприятия, первоначально принадлежавшего Якову (1832-1909) и Лазарю (1849-1914) Поляковым [2, с. 81-86; 14]. Общество братьев Поляковых просуществовало всего три года с 1891 г. по 1894 г., так и не развернув полностью свои операции. На их предприятие в Персии сразу же обратил внимание новый министр финансов Российской империи С.Ю. Витте (1849-1915), как только он занял свой пост в 1892 году. Последний, выступая на Особом совещании в Сенате, подчеркнул необходимость создания в Персии кредитного учреждения с большим оборотом денежных средств. Министр предложил вы- купить большую часть акций Ссудного общества братьев Поляковых, деятельность которого была не столь успешна, и превратить их предприятие в банк государственного типа, официально имеющего признаки частного учреждения. 4 мая 1894 г. проект С.Ю. Витте был обсужден в Министерстве финансов и спустя несколько дней утвержден императором Александром III (1881-1894) [3, с. 15].

Вскоре, Ссудное общество братьев Поляковых было выкуплено Министерством финансов России и реорганизовано в новое предприятие, получившее название Ссудный банк Персии. Отметим, что бывший владелец Яков Поляков отдал государству три четверти акций. Его брат Лазарь Поляков в течение несколько лет еще исполнял обязанности директора уже нового банка, но в конце 90 х гг. XIX в. братья Поляковы после многочисленных проверок со стороны Министерства финансов России были вынуждены совсем отказаться от своего участия в этом предприятии.

Кроме этого, они передали новому банку свой ломбард, что впоследствии позволило новым владельцам выдавать местному населению небольшие денежные ссуды под залог имущества и недвижимости.

Итак, с 90-х гг. XIX в. в Персию через этот реорганизованный банк устремляются государственные капиталы России, которые вкладываются в займы, концессии, в чеканку монет и другие финансовые операции персов, то есть Учетно-ссудный банк Персии стал проводником российской официальной политики в этой стране с 90-х гг. XIX в. и вплоть до 20-х гг. ХХ века.

Экономическая и финансовая деятельность банка довольно подробно освещена в монографиях академика Б.В. Ананьича, а также в работах отечественных (С.Г. Беляев, И.А. Руковицин и др.) и зарубежных исследователей (Е. Andreeva, A. Muried, K. Homa and others) $[2 ; 3 ; 5 ; 16 ; 25 ; 26 ; 28]$.

В данной статье, на основе неопубликованных и до сих пор мало использованных историками материалов Российского государственного исторического архива (РГИА, Санкт-Петербург) и Архива внешней политики Российской империи (АВПРИ, Москва), рассматриваются архивные документы, связанные с взаимоотношениями российских бан- 
киров с членами шахской семьи, персидскими купцами и местными агентами. Среди материалов фонда № 600 РГИА, содержащего сведения о деятельности Учетно-ссудного банка Персии, мы остановили свое внимание на двух не опубликованных до настоящего времени документах: «Дело о награждении персидских подданных орденами и медалями» и «Дело о покупке кинематографа». Обнаруженные нами сведения в Архиве внешней политики Российской империи проливают свет на создание банком разветвленной сети его агентств по всей Персии.

\section{II}

В 1898 г. председателем правления банка стал Петр Львович Барк (1869-1937) ${ }^{2}$. В состав правления вошли как представители государственной власти, так и члены императорской фамилии, великие князья Романовы (Владимир Александрович, Андрей Владимирович, Кирилл Владимирович). Банк быстро набирал обороты. Вскоре 77 процентов акций уже принадлежали государственным чиновникам, то есть Российское государство стало практически хозяином предприятия [8, л. 22-30].

В 1902 г. произошла еще одна реорганизация банка, который получил название «Учетно-ссудный банк Персии». Банк наделялся следующими функциями: предоставлять займы правящему шаху Мозаффар ад-Дину (1896-1907) и его окружению, активно развивать русскую торговлю в Персии, обеспечивать сбыт русских товаров, выдавать местному населению российские кредитные билеты, проводить меры по ограничению распространения английских товаров в северных районах Персии.

Все это позволяло русским активно вмешиваться во внутренние дела персов и соблюдать свои политические и экономические интересы в этой стране.

В скором времени Учетно-ссудный банк, кроме перечисленных выше функций, уже имел полномочия скупать земли у местного населения, особенно в северных районах страны и на побережье Каспийского моря. В отношении же своих соотечественников банк начал проводить все операции, связанные с ввозом русских товаров в Персию и их про- дажей, а также вывозом персидских в Россию. Таким образом, он стал посредником между русскими фабрикантами и персидскими купцами, как правило, клиентами банка [6, c. 308]. Без участия Учетно-ссудного банка не проходила ни одна процедура по оформлению русскими предпринимателями концессий у шахского правительства: на строительство шоссейных дорог, на право рыбной ловли, обустройства порта Энзели и др. Члены правления банка сами становились акционерами того или иного крупного проекта. Так, директором строительства Энзели-тегеранской дороги стал упомянутый выше председатель банка П.Л. Барк. Постепенно Учетно-ссудный банк открыл 5 своих агентств на территории России: в г. Ашхабаде (Асхабаде), Баку, Ереване, Джульфе, Мерве и Москве. В самой же Персии существовало 5 крупных отделений в главных городах страны: Мешхеде, Реште, Тавризе (современный Тебриз), Керманшахе, Тегеране и 9 небольших агентств в городах: Барфурше, Бендер-Гязе, Исфахане, Казвине, Кучане, Сабзеваре, Урмии, Хамадане, Энзели [9, л. 140-145; 10, л. 138].

Зачастую Учетно-ссудный банк открывал свои отделения там, где начинала работать какая-либо российская компания или строиться очередной участок шоссейной дороги. Так, в донесениях корреспондента журнала «Новое время» В.А. Шуфа ${ }^{3}$ мы встречаем описание тавризского отделения банка: «...Это превосходный банк, основанный по мысли графа Витте, как общество Тавризской дороги ...его постройка лучшая в Тавризе. Два его дома служащих банка и роскошная вилла управляющего А.И. Анастасинского тонут среди миндальных и персиковых деревьев. Сад прямо чудесен. На страже виллы стоят персидские казаки. Самый банк, находящийся в центре Тавриза, напоминает солидный барский особняк» [23, с. 5]. Из его же донесения явствует, что банк совершал операции не только в русских рублях, но и в персидских кранах. Таким образом, денежные операции банка, как мы видим, были рассчитаны на привлечение финансов не только российских предпринимателей, но и персов. Денежный оборот в персидских кранах позволил банку увеличть объем своих торговых операций с местным населением, выдавая им под- 
товарные ссуды и удобный для них кредит. Расширение функций банка вызывало недовольство целого ряда русских компаний, пострадавших от неожиданной конкуренции со стороны банка. Еще один русский путешественник Б.М. Гурьев, проезжая через Тавриз, писал: «Здание нашего отделения Учетно-ссудного банка Персии находится в минутах двадцати езды от дома управляющего. Оно расположено около самого базара. В первой комнате, у входа, находится выставка образцов русских товаров» [7]. Таким образом, помещение банка использовалось для своеобразной рекламы русских товаров, особенно если учесть его местоположение вблизи городского базара (см. рис. 1).

Управляющие отделениями и агентствами Учетно-ссудного банка являлись также информаторами происходящих событий в своих городах. Будучи очевидцами и свидетелями увиденного, они сообщали в своих депешах сведения об обстановке в городе Э.К. Грубе, начальнику центрального отделения банка в Тегеране. Последний в свою очередь передавал полученную от них информацию в СанктПетербург. Так, Э.К. Грубе, основываясь на донесениях представителя тавризского отделения господина Борового, сообщал в своей телеграмме от 22 мая 1903 г. о крупных волнениях в Тавризе: «... Тавриз. Беспорядки. Базары закрыты. Банк тоже. Беспорядки направлены против нового тарифа новой дороги, против европейцев на персидской службе, против продажи крепких напитков, школ... Полный хаос таможенного управления» [11, л. 150]. Подобные сообщения очень важны для понимания начала революционных массовых выступлений персов, приведших страну к конституционной революции 1905-1911 годов.

Дирекция банка четко действовала в рамках геополитических интересов России. Так, выполняя условия договора 1907 г. о разделе сфер влияния в Персии между Россией и Англией, Учетно-ссудный банк прекращает свои операции и закрывает отделение в провинции Сеистан, которая по упомянутому соглашению уже находилась в зоне англичан [10, л. 137].

В 1915 г. основной капитал Учетно-ссудного банка составлял уже 11,875 млн руб. [11, л. 121]. К этому времени российские промышленники практически могли внедрять свои проекты в Персии только при посредничестве Учетно-ссудного банка, который давал разрешение на проведение тех или иных начинаний. Напротив, те предложения, которые не отвечали интересам дирекции банка или вызывали у его руководства сомнения, оставались невыполнимыми. Так, был отклонен проект, имя автора которого пока не удалось установить, о строительстве керосинового провода через территорию Персии от побережья Каспийского моря до Персидского залива. Особое совещание в Санкт-Петербурге, рассматривавшее этот вопрос не без участия банка, вынесло решение «оставить без последствия» [11, л. 77]. Вполне возможно, на это повлияли геополитические соображения участников совещания, не стремившихся вступать в переговоры с англичанами по поводу этого строительства.

\section{III}

Наряду с выполнением вышеперечисленных функций дирекция банка в Тегеране внимательно следила за работой русских подданных и своих чужеземных помощников - агентов, которые были выходцами не только из Персии, но и из Азербайджана, Средней Азии и Европы. Последние проводили свои операции через банк и оказывали русским банкирам «различные услуги». Анализируя архивные материалы РГИА, можно представить четкую картину, какие именно услуги оказывали те или иные партнеры, и выяснить, какими именно русскими орденами и медалями они награждались Учетно-ссудным банком. Это были: золотая медаль на ленте Святой Анны; орден Святой Анны І-й степени и III-й степени; орден Святого Станислава II-й степени и III-й степени ${ }^{4}$.

Правление банка тщательно изучало списки лиц, представленных к наградам отделениями и агентствами, сохраняя за собой право оставлять некоторые кандидатуры без поощрений. Так, в архивных материалах банка, датируемых мартом 1905 г., мы находим данные о том, что дирекция банка, рассматривая список лиц к награждению, отказала представить к награде двух человек по тавризскому отделению: чиновника по иностранным делам (каргузара) Амир Тумана Хаджи Моззахера ад - Доуле и церемониймейстера 
двора, наследника престола Амир Мирза Хабибу. В резолюции указывалась, что «они имеют только косвенное отношение с Банком и награждаются миссией через Министерство иностранных дел» [12, л.18].

В «Деле о награждении» приводится специальная таблица, согласно которой можно определить имя награждаемого, его национальность, с каким отделением банка он сотрудничал, чем занимался и мотивацию для награждения. Данный список утверждался русской миссией в Тегеране.

Из исследуемой таблицы явствует, что в начале марта 1905 г. (очевидно это проводилось по итогам предыдущего года) правление Учетно-ссудного банка наградило 20 человек: двенадцать из них сотрудничали с тегеранским отделением, семь - с тавризским и один - с мешхедским. Из них можно выделить две категории награждаемых: к первой относились служащие, ко второй - купцы, тесно связанные с банком. Среди них восемнадцать человек были купцами или торговыми агентами и два человека - переводчиками. Одним из последних был Мирза Сайид Абдулла-хан, старший переводчик тегеранского отделения, работавший там в течение четырнадцати лет. Кроме своей непосредственной работы, он информировал банк о платежеспособности и надежности клиентов. Мирза Сайид был награжден орденом Святой Анны III-й степени [12, л. 15-16].

В списке среди награжденных купцов на первом мете стоял Моавин Тоуджар. В письме-ходатайстве управляющего мешхедским отделением от 23 февраля 1905 г. указывалось: «Покорнейше прошу исходатайствовать ему (Моавину Тоуджару. - И. П.) золотую медаль на шею, так как дать ему серебряную медаль было бы не совсем удобно» [12, л. 10]. Кандидатуру упомянутого купца поддержал лично П.Л. Барк.

По тегеранскому отделению был представлен к награде золотой медалью на ленте Святой Анны на шею Хаджи Сайид Хосайн Ладживерди, так как он был «крупным маклером по сахарным и чайным сделкам, очень полезный человек для Банка и вообще для русской торговли в Персии» [12, л. 18]. Судя по награде, Хаджи Сайид сообщал вполне полезную информацию русским. Такой же награды был удостоен Хаджи Мохаммад Багир
Асанов, занимавшийся импортом из России стеклянных и медных изделий.

Многие из купцов, как явствует из таблицы, сотрудничали с русскими фабрикантами и промышленниками еще до основания банка. Они торговали с Россией около 30 лет, пользовались безукоризненной репутацией в торговом мире, способствовали ввозу русской мануфактуры в Персию. Среди них назовем имена Хаджи Мирза Али Исфахани, Каспархана Тер-Мелькумова, Хаджи Абдулла Мохаммада [12, л. 14-16].

В упомянутой таблице встречается имя офицера бельгийской армии в отставке Жозефа Флебюса, который в ту пору занимал должность директора почтовых дел в Азербайджане. Он сумел организовать регулярное сообщение с Джульфой, причем довольно часто (три раза в неделю), что помогало банку оперативно пользоваться обменом информации с Россией. Кроме этого, в ходатайстве о его награждении указывалось: «Благодаря ему, Банком заключены с почтой льготные контракты на пересылку денежных сумм для всех корреспондентов Банка» [12, л. 20]. Правление наградило Жозефа Флебуса орденом Святой Анны III-й степени.

Правление учитывало также срок службы представленного к награде. Так, на ходатайство Бендергязского агентства о награждении своих сотрудников к новому 1914 г. золотыми часами фирмы Эриксона или Буре с монограммой банка, оно ответило отказом «ввиду кратковременности функционирования» агентства. Действительно, упомянутое агентство работало только полтора года, с середины 1912 года. Вполне возможно, на это решение повлияла также стоимость часов. По подсчетам дирекции, сумма покупки равнялась бы 400-600 руб. [12, л. 42-44].

Вышеприведенные сведения свидетельствуют о довольно значительном круге местных купцов, работающих для Учетно-ссудного банка Персии, о разветвленной сети своих агентов во многих городах страны, добывающих важную информацию для банка и поддерживающих русскую торговлю. Упомянутые российские награды, вручаемые иностранцам, и в России имели высокую степень важности, поэтому мы можем говорить об определенном уровне отношений между двумя странами. 
IV

Деятельность Учетно-ссудного банка, как явствует из архивных документов, не ограничивалась только финансовыми и торговыми операциями в Персии. Председатель правления банка П.Л. Барк и заведующий центральным тегеранским отделением Э.К. Грубе соблюдали определенный политический политес по отношению к шаху и его окружению, преподнося последним дорогостоящие подарки. Так, в архивных документах банка нами было обнаружено «Дело о покупке кинематографа», проливающее свет на взаимоотношения руководства банка с членами шахской семьи [13]. В частности, из этого документа мы узнаем о весьма неординарном подарке, сделанном П.Л. Барком наследнику престола Мохаммаду Али. Мотивы такого подношения, очевидно, кроются, прежде всего, в желании укрепления дальнейших российско-персидских отношений уже после прихода наследника к власти. Добавим также то, что в эти годы правящий шах Мозаффар адДин был болен, часто впадал в припадки и, действительно, через три года (в 1907 г.) он скончался. Поэтому расчет П.Л. Барка, на наш взгляд, очевиден. Еще раньше в одном из донесений управляющего тавризским отделением банка сообщалось: «...при посещении дворца (наследника. - И. П.) постоянно приходится раздавать на “чай” и затем как и мне, так и жене, которая посещает принцессу необходимо время от времени делать подарки» [13, л. 34].

В упомянутом «Деле о покупке кинематографа» содержатся телеграммы, письма, накладные, посылаемые из Тегерана в СанктПетербург и обратно, связанные с покупкой киноаппарата и кинолент («движущиеся картинки») и предназначенные в качестве подарка наследственному принцу (Валиахду).

В телеграмме Э.К. Грубе от 4 ноября 1904 г. из Тегерана в Санкт-Петербург говорилось: «Прошу выслать возможной скоростью предложенный подарок Наследнику кинематограф с набором картин. Для картин, кроме обычных веселых сюжетов, прошу доставить снимки частной жизни царского семейства, железной дороги, событиях войны (русско-японской войны 1904-1905 гг. -
И. П.), все это тщательно уложить в несколько ящиков и отправить почетными посылками, расчетом получить здесь в конце ноября» $[13$, л. 1]. Отметим, что строительство железных дорог в Персии появится только после 1910 г., поэтому эти сюжеты явно должны были заинтересовать наследника. Вместе с тем необходимо было выслать электромотор стоимостью 1200 руб. и динамомашину (современный электрогенератор постоянного тока) весом 20-22 пуда для освещения показа фильмов.

В Петербурге отреагировали на этот запрос незамедлительно. Необходимые картины были отобраны в двух тогда известных петербуржских фотосалонах: первый из них принадлежал придворному фотографу К.Е. Гану, хозяином второго был владелец торгового дома и магазина «фотографических принадлежностей» Ф. Иоахим ${ }^{5}$. Прежде всего, упомянутые персоны предоставили правлению банка список картин, которые П.Л. Барк тщательно изучил. Он выбрал из каталога К.Е. Гана, занимающегося хроникой императорского двоpa, такие картины, как: «Прибытие императорской яхты Александрия», «Ливадия. Танцующие Великие княжны во дворце», «Ливадия. Отъезд Его Величества», «Юбилей Санкт-Петербурга. Открытие Троицкого моста» (имеется в виду празднование двухсотлетия Санкт-Петербурга. - И. П.) и другие картины подобного плана. Общая стоимость этих документальных фильмов, протяженностью 475 м, составила 712 руб. 50 коп. В магазине Ф. Иоахима были заказаны 37 кинематографических картин (или 1080 м), такие как «Катание на лодках», «Засада», «Нападение на поезд» и др., стоимостью 864 руб. и 45 картинок (очевидно, имеются в виду слайды для волшебного фонаря на сумму 60 руб. 70 коп.). Стоимость одного слайда, как указывается в докладной записке, составляла 1 руб. 35 коп. Таким образом, заказ у Ф. Иоахима вышел на сумму 924 руб. 70 коп. [13, л. 14]. Судя по названиям, в фотомагазине были куплены в основном художественные фильмы.

Анализируя каталог проекционных картин магазина Ф. Иоахима, а он содержал 587 рубрик, мы обратили внимание на рубрику № 562 с заголовком «Персия». В этой руб- 
рике перечисляется 18 названий картин, непосредственно касающихся истории, архитектуры, культуры этой страны. Например, «Персия, дервиш и нищий», «Тегеран», «Персияне» и др. В настоящий момент трудно сказать, каким образом эти фильмы попали в магазин $Ф$. Иоахима, но их наличие дает нам право говорить о спросе зрителей и о желании русских людей познакомиться с историей и культурой своего ближайшего соседа.

В общей сложности правление Учетноссудного банка Персии, включая стоимость всех покупок, транспортировку груза и его страховку, заплатило за «удовольствие наследника» немалую по тем временам сумму 4113 руб. 65 коп. По одной из накладных, содержащихся в «Деле», мы также узнаем о том, что транспортировкой груза и его страховкой занималось Российское транспортное и страховое общество, известное сотрудничеством с Персией еще с 1844 года.

Тем не менее именно такой подарок русских (напомним, что Учетно-ссудный банк Персии являлся филиалом государственного банка России и представлял интересы своей страны) был действительно неординарным, дорогим по своей стоимости и, несомненно, должен был заинтересовать наследника, так как кинематограф в Персии в то время был практически неизвестен и являлся техническим новшеством даже для персидской знати [13, л. 18]. Тщательный подбор подарка П.Л. Барком и стоимость подношения говорят нам о том, что для укрепления русскоперсидских отношений высокопоставленные чины России готовы были пойти на любые варианты. Доставить этот подарок необходимо было именно в г. Тавриз (Иранский Азербайджан) в резиденцию наследника Мохаммада Али, а не в Тегеран, где находился шах со своей свитой. В депеше П.Л. Барка перед управляющим тавризским отделением банка В. Будиловичем ставилась непосредственная задача донести до наследника информацию о том, что киноаппарат с фильмами является эксклюзивным подарком Учетно-ссудного банка Персии. Кроме этого, демонстрировать показ фильмов предназначалось только для наследника и, стационарно установив киноаппарат во дворце Мохаммада Али, не перевозить его в Теге- ран. В частности, П.Л. Барк писал: «Кинематограф, как Вам известно, предназначен в качестве подарка Наследнику шахского престола, должен быть преподнесен Вам Его Высочеству и установлен г. Николаевым во дворце Валиахда, вследствие чего демонстрация его (кинопоказа. - И. П.) в банке или посторонним лицам является, конечно, нежелательной» [13, л. 25].

Доставить все сделанные закупки из Санкт-Петербурга в Тавриз поручили классному техническому мастеру Михайловской артиллерийской академии А.Н. Николаеву. Последний получил от банка на проезд 500 руб. и в качестве поощрения после выполненной работы 450 руб. (сначала ему выдали в качестве премии 300 руб., а затем из-за трудностей переезда еще 150 руб.). Перед своим отъездом А.Н. Николаев дал обязательство довести все это имущество в целости и сохранности, подключить аппарат для просмотра фильмов во дворце наследника, а также обучить пользоваться кинопринадлежностями и динамомашиной кого-либо из персонала Мохаммада Али. Естественно, что никто из персов еще не имел опыта обращения с киноаппаратом.

Из документов становится известно, что А.Н. Николаев выехал из Санкт-Петербурга 25 декабря 1904 г. и 8 января прибыл в Тавриз, то есть его переезд длился 15 дней, и даже новый 1905 г., как мы видим, он был вынужден встретить в дороге. 10 января прибыли киноаппарат и динамомашина, а 13-го числа этого же месяца доставлены киноленты. Все это перевозилось через персидскую таможню в г. Джульфе [13, л. 23].

Зима в ту пору в Иранском Азербайджане была довольно холодная, в Тавризе морозы достигали минус 20 градусов. Несмотря на холод и длительный путь, все кинопринадлежности дошли до Тавриза в хорошем состоянии, кроме динамомашины, из которой после тряски в дороге вылетели нужные болты и сломались пластины. В течение нескольких дней А.Н. Николаев с помощью некого молодого человека Багирова из прислуги наследника, татарина по происхождению, устранил поломку и привел все необходимое для просмотра кинолент в рабочее состояние. За эти же дни А.Н. Николаев также сумел обучить 
Багирова техническим приемам для дальнейшей работы.

Итак, 16 января, в воскресенье 1905 г., наследнику был вручен подарок Учетно-ссудного банка, и в этот же день прошел первый показ фильмов. Об этом В. Будилович писал председателю банка П.Л. Барку: «Кинематоргаф произвел на Его Высочество самое лучшее впечатление. Во время представления я сидел рядом с Его Высочеством, в то время как все приглашенные стояли. Я объяснял Валиахду содержание каждой картины. Его Высочество также занимало меня разговорами на русском языке, на котором он, если не стесняется, говорит довольно хорошо. Особенное впечатление на Его Высочество произвели парады, смотры (войск. - И. П.) и петербургские улицы. Валиахд все время мечтает о поездке в Петербург, в чем ему Правительство (шаха. И. П.) постоянно отказывает. Видя пробегающие картины (Петербурга. - И. П.) Валиахд все время удивлялся и повторял: «Когда же, наконец, я сам все это увижу?» [13, л. 33-35 об.].

Просле просмотра наследник заявил, что «в Тегеране у Шаха видел слабое подобие, но такого киноаппарата у Шаха нет» [13, л. 34]. Как предположил В. Будилович, «у шаха, вероятно, находился волшебный фонарь-диарама», поэтому преподнесенный киноаппарат был в новинку наследнику и его приближенным. В заключение сеанса и общения с В. Будиловичем Мохаммад Али даже похвастался и сказал, что сам умеет фотографировать. Он попросил управлящего купить ему «небольшой современный аппарат для моментальных съемок». По случайности (или намеренно был приготовлен?), фотоаппарат в этот момент также оказался при В. Будиловиче. Последний в своем упомянутом письме сообщал: «Мне оставалось одно - просить Его Высочество принять этот аппарат» [13, л. 34]. Валиахд был чрезвычайно тронут присланными подарками. В благодарность за это наследник решил послать председателю банка П.Л. Барку свою фотографию. При этом он добавил: «Я поищу фотографию, снятую с меня в Тегеране, она, кажется, лучше прежних. Если же не найду, то нарочно снимусь» [13, л. 34-34 об.]

Так, закончился первый показ фильмов во дворце наследника, правление банка планировало провести еще подобные сеансы, тем бо- лее, что через месяц, в начале марта того же года, прибыла вторая партия кинолент из фотосалона К.Е. Гана. Очевидно, в первую посылку не вошли все отобранные ранее фильмы. Второй сеанс показа фильмов состоялся 11-го марта упомянутого года. В своей докладной П.Л. Барку В. Будилович писал: «Эта серия доставила Его Высочеству особенное удовольствие, и он просил меня выразить Вам особенную Его признательность за все труды и прекрасный подарок и переслать Вам на добрую память приложенную при сем фотографическую карточку с его собственной подписью» $[13$, л. 143]. Как мы видим, Мохаммад Али выполнил свое данное ранее обещание и переслал председателю банка свою фотографию. Еще один показатель хороших отношений наследника с банком.

Предполагалось продолжить киносеансы, так как планировалось, что наследник будет оставаться в Тавризе еще длительное время. Однако 15 марта, буквально через 4 дня после показа, Мохаммад Али, получив телеграмму о плохом состоянии здоровья своего отца, срочно выехал в Тегеран. В своей депеше в правление банка В. Будилович сообщал крайне важные сведения о состоянии дел в Тавризе: «Валиахд выехал настолько экстренно, что он не дождался своего нового заместителя нового наследника Низам ас-Салтане, который пребывает только в конце недели. Так как в городе голод и страшная нужда, благодаря стачке помещиков, удерживающих хлеб в амбарах, то все ожидали с отьездом Валиахда голодного бунта простонародья, то есть разноса амбаров и домов известных повышателей цен... Благодаря бездорожью, банк, к сожалению, не может сейчас вмешаться в это дело» [13, л. 143 об.]. Скорее всего, под последней фразой имелось в виду, что банк не мог ускорить приезд нового наследника Низам ас-Салтане. Здесь же В. Будилович сообщал о возможности прихода к власти Мохаммада Али: «Говорят, здоровье Шаха настолько плохо, что много вероятности в том, что Валиахд заменит его окончательно. Говорят, умственные способности Шаха совершенно ослабели, он страдает нервными припадками, вроде эпилепсии» [13, л. 143 об.].

На этом заканчивается «Дело о покупке кинематографа». Очевидно, дальнейшие революционные события в Персии в 1905 г. и про- 
грессирующая болезнь Мозаффара ад-Дина не позволили устраивать такие дружеские сеансы управляющего тавризским отделением банка и наследника Мохаммада Али. Может быть, в этом и отпала необходимость, ведь киноаппарат был уже установлен во дворце наследника и подготовлен для демонстрации фильмов, как уже упоминалось, механиком Багировым. Задумка П.Л. Барка подарить наследнику киноаппарат с фильмами была выполнена блестяще.

Согласно анализируемым данным, можно говорить о том, что демонстрация фильмов из России формировала мировоззрение персидской знати, открывала перед ней возможность познакомиться не только с Россией, но и с европейскими техническими новшествами. Упомянутый подарок Учетно- ссудного банка явился толчком к появлению и развитию киноискусства в этой стране $^{6}$.

Таким образом, вышерассмотренные материалы российских архивов, часть которых до сих пор остается вне поля зрения исследователей, являются важным дополнением к уже известным фактам о деятельности Учетно-ссудного банка Персии. Они служат яркой иллюстрацией, демонстрирующей разнообразные функции банка, направленные на развитие и укрепление русско-персидских отношений. Все вышесказанное еще раз подтверждает прочные позиции Учетно-ссудного банка Персии, представлявшего государственные интересы России, в этой стране. Для официальных российских властей существование такого финансового монополиста в Персии было крайне важно в связи с обостряющимся соперничеством в этом регионе с Англией. Обнаруженные нами документы демонстрируют, каким образом через деятельность банка российское правительство смогло значительно расширить сферы своего влияния в Персии, и констатируют государственное вмешательство Царской России во внутренние дела Персидского государства.

\section{ПРИМЕЧАНИЯ}

1 В данной статье мы сохраняем название «Персия», так как эта страна указывается в исполь- зованных нами архивных документах XIX - начала ХХ века.

${ }^{2}$ П.Л. Барк занимал пост председателя правления Учетно-ссудного банка с 1898 по 1905 год [4; 15, c. 335-336; 18]. Само же правление Учетно-ссудного банка Персии находилось в Санкт-Петербурге, в доме 30/32 по Екатерининскому каналу (современное название - канал Грибоедова), в том же здании, где располагался Государственный банк России. Добавим также то, что после Октябрьской революции в России в 1917 г. Учетно-ссудный банк Персии продолжал проводить небольшие операции в Тегеране. Он прекратил свое существование только в 1921 г., когда, согласно условиям подписания советско-иранского договора, советское правительство передало его персидскому шаху (см. рис. $[19$, с. $74-82 ; 20]$.

${ }^{3}$ Шуф (Борей) Владимир Александрович (01.01.1865-02.11.1913) - поэт Серебряного века, публицист, корреспондент. В литературных кругах был известен под псевдонимом Борей. В конце 1911 г. он отправился из Санкт-Петербурга в Персию в качестве корреспондента журнала «Новое время» [23, с. 5].

${ }^{4}$ Орден Святой Анны утвержден как династийная награда в 1735 году. Позже при императоре Павле I (1796-1801) стал императорским орденом. С 1797 г. - государственной наградой для поощрения широкого круга чиновников и военных. Представлял собой серебряную позолоченную медаль с изображением орденских знаков. Отличался по размерам: I степени - $52 \times 52$ мм; II степени $44 \times 44$ мм; III степени - $35 \times 35$ мм; орден Святого Станислава - царский и императорский орден, самый младший по старшинству в иерархии государственных наград для отличия чиновников и награждения иноверцев [17].

5 Фотосалон «фотографа Его Величества» К.Е. фон Гана и Кㅇ был известен с 1891 года. Он находился в Царском селе, летней резиденции российских императоров (27 км от Санкт-Петербурга), на улице Широкой в доме Бернаскони около железнодорожного вокзала. В настоящее время дом не сохранился (см. рис. 3) [24]. Торговый дом (Товарищество на паях) с магазином фотопринадлежностей Ф. Иоахима и Кㅇ был основан в 1860 году. Вскоре компания начала торговать в Санкт-Петербурге, на Невском проспекте в доме 3 , и в Москве, на улице Мясницкой в доме 36. Фирма Ф. Иоахима также являлась поставщиком двора Его Императорского Величества и считалась единственным представителем известного английского завода Ильфорд (см. рис. 4) [1].

${ }^{6}$ Первые фильмы персидского (иранского) производства появятся в этой стране лишь в конце 80-х гг. ХХ столетия [27]. 


\section{ПРИЛОЖЕНИЯ}

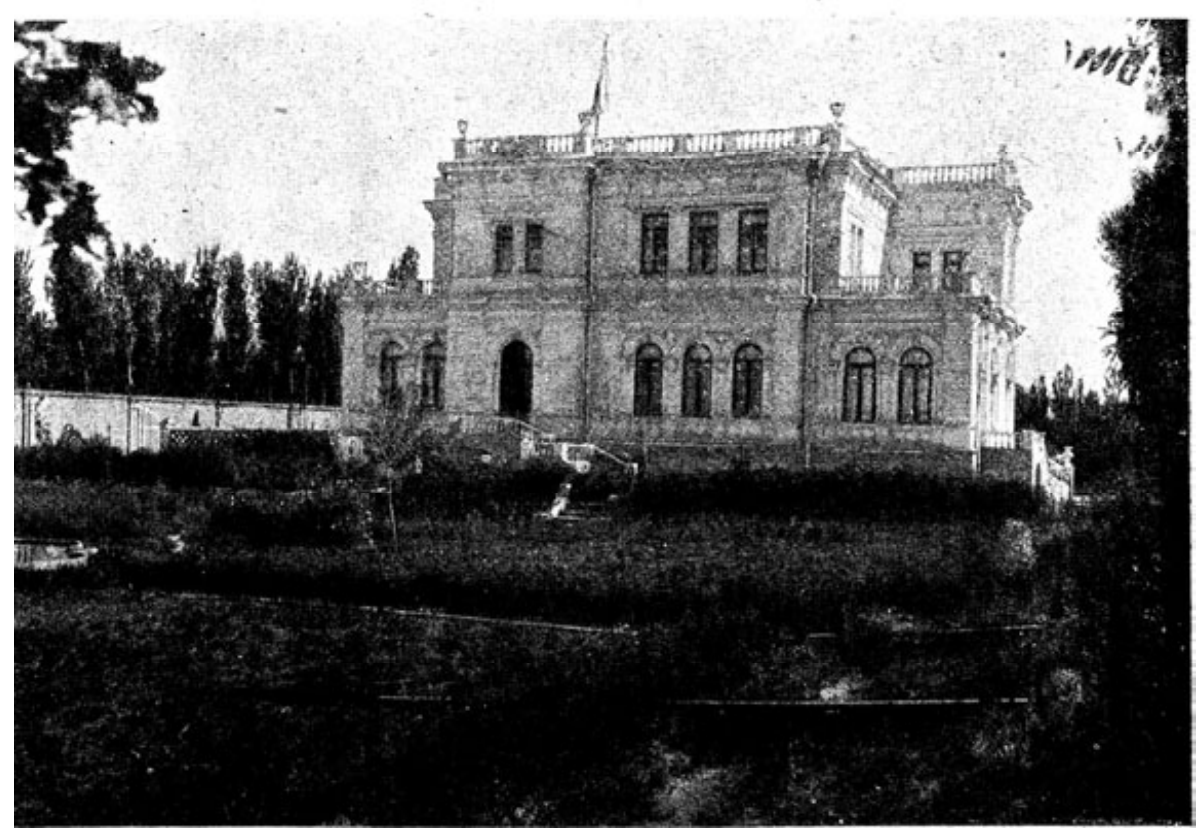

Рис. 1. Дом управляющего Тавризским (совр. Тебризским) отделением Учетно-ссудного банка

Fig. 1. House of Director of Taurisian (now Tebrizian) department of Loan and Account Bank

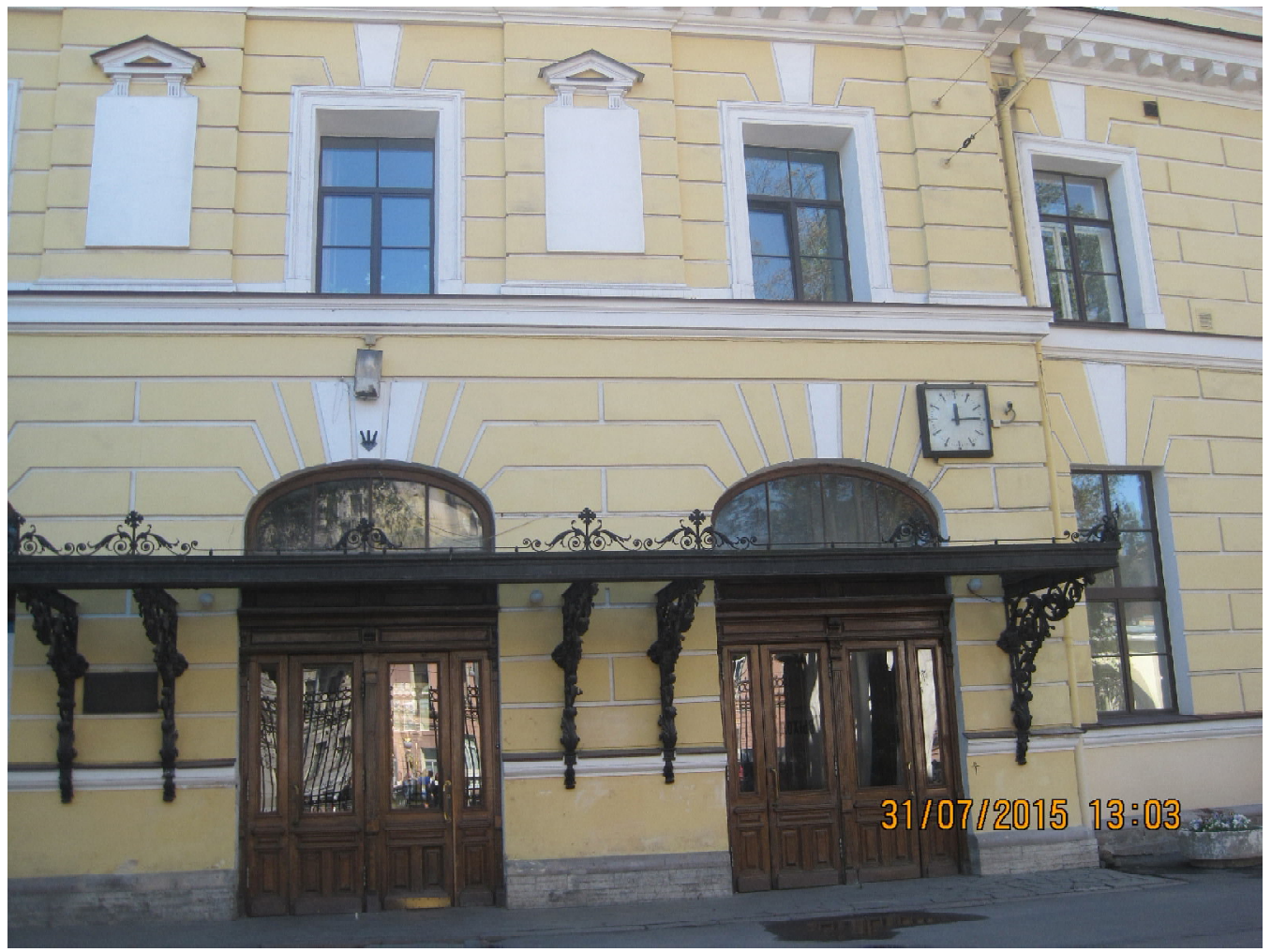

Рис. 2. Здание Учетно-ссудного банка - Санкт-Петербург, Екатерининский канал (канал Грибоедова), 30/32

Fig. 2. Building of Loan and Account Bank - Saint Petersburg, Ekaterininsky Channel (Channel of Griboedov), 30/32 


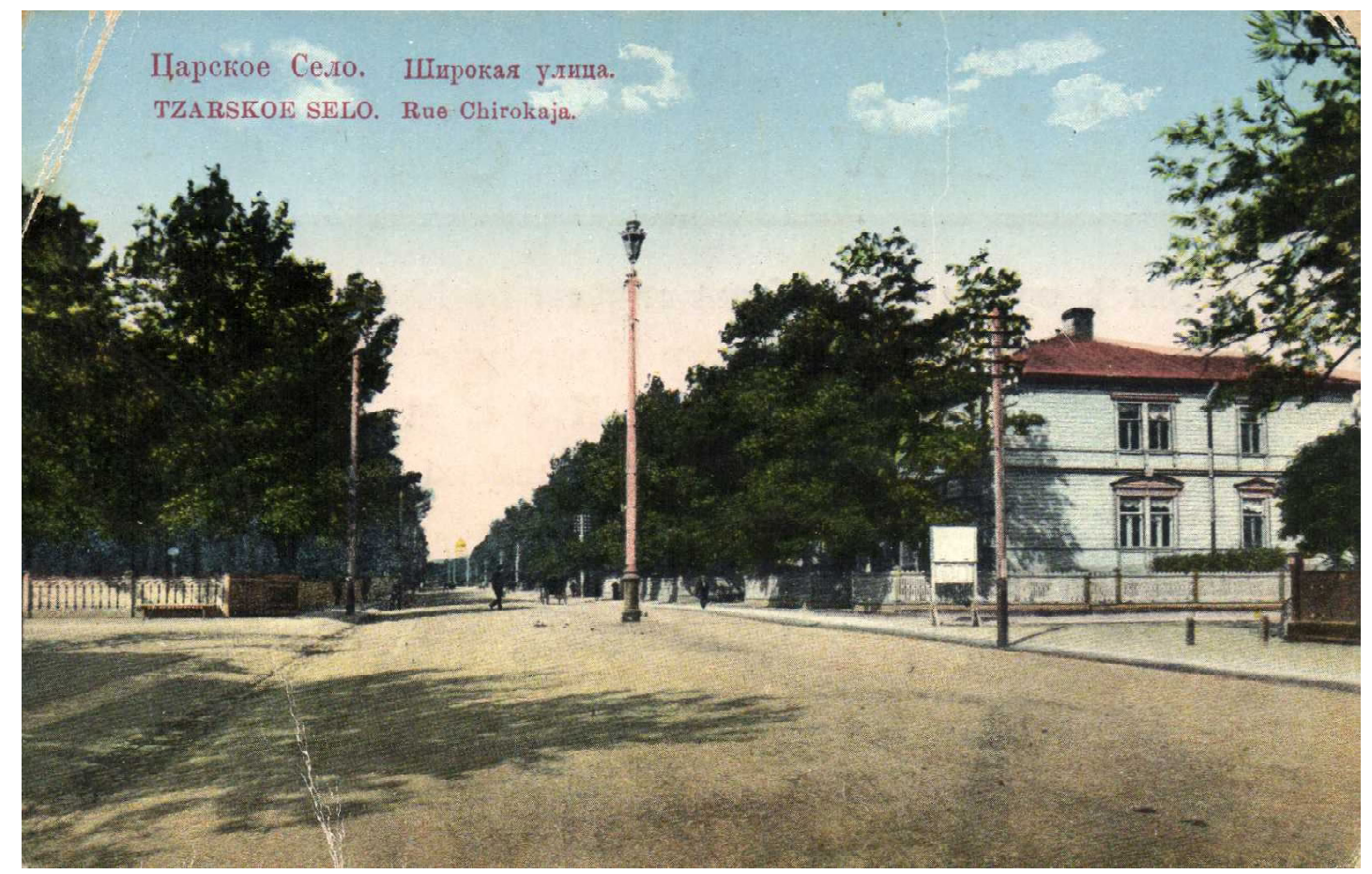

Рис. 3. Фотосалон К.Е. фон Гана - Царское село, ул. Широкая

Fig. 3. Photostudio of K. E. fon Gan - Tsarskoe selo (Tsar Village), Shirokaya St.

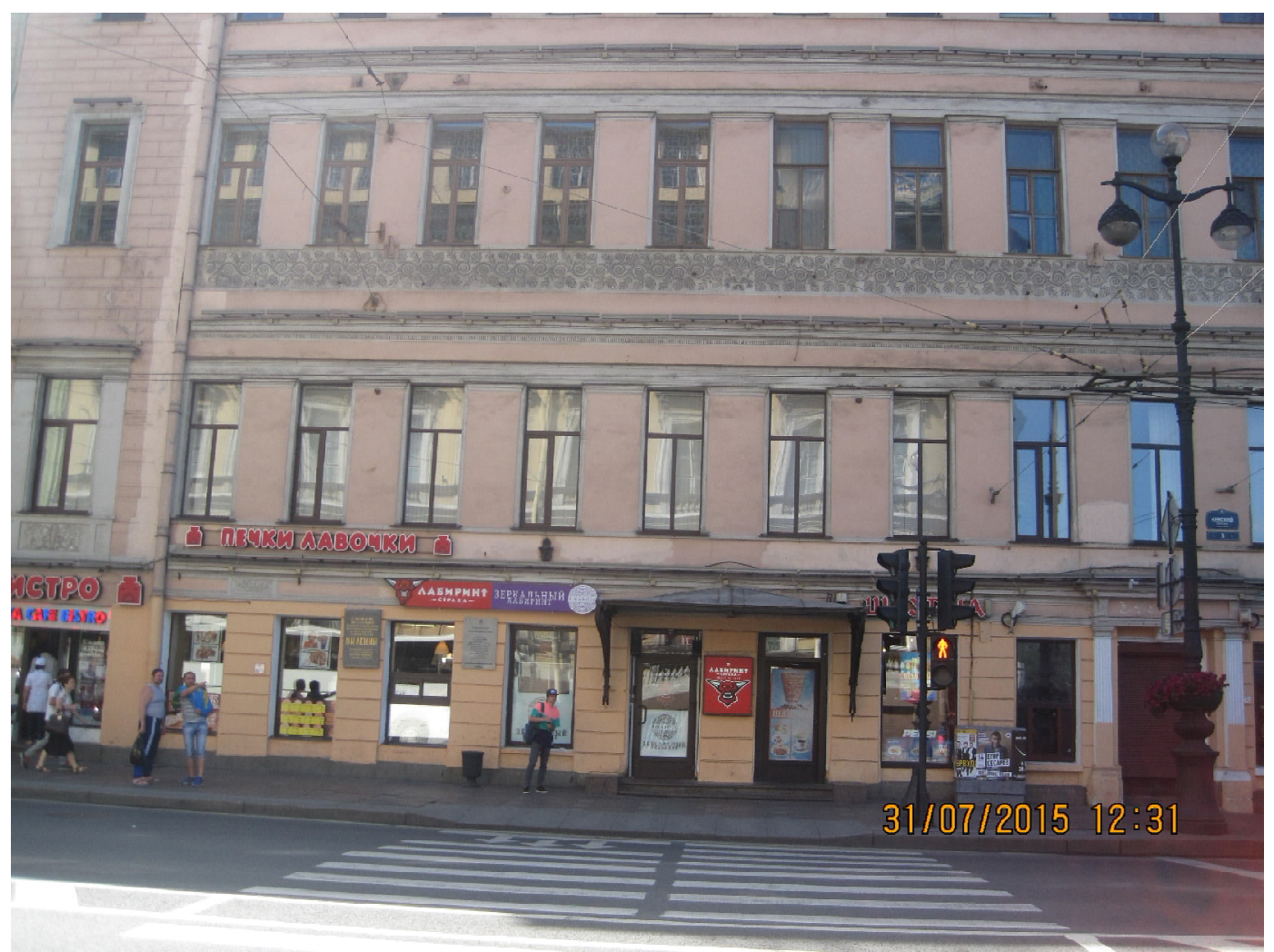

Рис. 4. Фотомагазин Ф. Иоахима - Санкт-Петербург, Невский проспект, 3

Fig. 4. Photoshop of F. Ioahim - Saint Petersburg, Nevsky Prospect 


\section{СПИСОК ЛИТЕРАТУРЫ}

1. Абрамов, Г. Этапы развития отечественного фотоаппаратостроения. Торговый дом Ф. Иоахима и Ко. - Электрон. текстовые дан. - Режим доступа: http://photohistory. ru/1207248166951435 html. Загл. с экрана.

2. Ананьич, Б. В. Банкирские дома в России. Очерки по истории частного предпринимательства / Б. В. Ананьич. - 2 изд., доп. - СПб. : Санкт-Петербургский Институт истории РАН, 2006. - 295 с.

3. Ананьич, Б. В. Российское самодержавие и вывоз капиталов 1885-1914. По материалам Учетно-ссудного банка Персии / Б. В. Ананьич. - Л. : Наука, 1975. - $211 \mathrm{c}$.

4. Беляев, С. Г. П.Л. Барк и финансовая политика России 1914-1917 гг. / С. Г. Беляев. - СПб. : СПбГУ, 2002. $-620 \mathrm{c.}$

5. Беляев, С. Г. Учетно-ссудный банк Персии в годы Первой мировой войны / С. Г. Беляев // Россия в XIX-XX вв. - СПб. : С.-Петерб. фил. Ин-та Рос. истории РАН, 1998. - С. 276-285

6. Вестник финансов, промышленности и торговли. - СПб. : Министерство финансов, 1903. - Т. IV, № 48. - С. 308

7. Гурьев, Б. М. Поездка в Тавриз: Учетноссудный банк Персии / Б. М. Гурьев // Библиотека древних рукописей. Раздел VII. - Электрон. текстовые дан. - Режим доступа: http:/www/drevlit.ru/ docs/iran/XX/1900-1920/,Gurjev B/M/text10eb/php. Загл. с экрана.

8. Дела о заграничных денежных операциях. Комитет финансов (1813-1918) // Российский государственный исторический архив (РГИА). - Ф. 563. Оп. 2. - Д. 231. - Ед. хр. 1035.

9. Дела Учетно-ссудного банка Персии (19001921) // Архив внешней политики Российской империи (АВПРИ). - Ф. «Персидский стол». Оп. 400. - Д. 916.

10. Дела Учетно-ссудного банка Персии (19001921) // АВПРИ. - Ф. «Среднеазиатский стол». Оп. 485. - Д. 2768. - Ч. II.

11. Дело о дорожном строительстве в Персии. Дерпартамент железных дорог в России МФ (19021903) // РГИА. - Ф. 268. - Оп. 2. - Д. 3875. Ед. хр. 1036.

12. Дело о награждении ряда персидских подданых русскими орденами и медалями. Учетноссудный банк Персии МФ (1904-1915) // РГИА. Ф. 600. - Оп. 2. - Д. 1460. - Ед. хр. 45.

13. Дело о покупке кинематографа. Учетноссудный банк Персии МФ (1904-1905) // РГИА. Ф. 600. - Оп.4. - Д. 33. - Ед. хр. 150.

14. Заславская, И. Братья Поляковы-коммерсанты, дворяне, евреи / И. Заславская // Заметки по еврейской истории. - 2011. - № 10 (145) (окт.). - Электрон. текстовые дан. - Режим доступа: http://www.berkovichzametki.com/November/2011.--Загл. с экрана.

15. Российская банковская энциклопедия (РБЭ) / под ред. О. Н. Лаврушина [и др.]. - М. : ЭТА, 1995. $552 \mathrm{c}$.

16. Рукавицин, И. А. Учетно-ссудный банк Персии как часть русской политики на Востоке / И. А. Рукавицин // Филократия. - М., 2012. № 2 (27). - Электрон. текстовые дан. - Режим доступа: http://www.oldbank.info. - Загл. с экрана.

17. Серков, С. Р. Орден Святой Анны. Орден Святого Станислава / С. Р. Серков // Военно-исторический журнал. - М. : Минобороны РФ, 1990. - № 5. - Электрон. текстовые дан. - Режим доступа: http:/www/soldat/ ru/spravka/issuevj/vij-1990. - Загл. с экрана.

18. Смирнова, Н. И. Петр Львович Барк (06.04.1869-16.01.1937) - чиновник, банкир и последний министр финансов Российской империи / Н. И. Смирнова, Т. М. Образцова. - Электрон. текстовые дан. - Режим доступа: http://nlab.ru/editions/ publics/751/3256 (дата обращения: 30.05.2008). - Загл. с экрана.

19. Советско-иранские отношения в договорах, конвенциях, соглашениях. - М. : Министерство иностранных дел, 1946. -216 с.

20. Учетно-ссудный банк Персии (1917-1920) // Государственный архив Российской Федерации (ГАРФ). - Ф. Р-4720. - ОП.1. - Д.1. - Ед. хр.1.

21. Фируз, К. Борьба за влияние в Персии. Дипломатическое противостояние России и Англии.Электрон. текстовые дан. - Режим доступа: http:// statehistory.ru/book/www//livejournal.com. - Загл. c экрана.

22. Шилов, Д. Н. Государственные деятели Российской империи 1802-1917. Библиографический справочник / Д. Н. Шилов. - СПб. : Дмитрий Буланин, 2001. -830 с.

23. Шуф (Борей), В. А. Корреспонденция об экспедиции в Персию. Русский банк и торговля в Тавризе / В. А. Шуф (Борей) // Новое время. - 1912. № 12897 (7 февр.). - Электрон. текстовые дан. - Режим доступа: http://v.shuf/narod/ru/public3html. Загл. с экрана.

24. Энциклопедия Царского села. - Электрон. текстовые дан. - Режим доступа: http:/ www. Tsarselo.ru/yenciklopedijatsarkogosela/nauka-i tehnikavtsarkomsele/totele. - Загл. с экрана.

25. Andreeva, E. Russia and Iran in the Great Game / E. Andreeva // Travelogues and Orientalism. L. : Routledge, 2007. - 288 p.

26. Homa, K. State and Society in Iran.The eclipse of the Qajars and the emergence of the Pahlavi's / K. Homa. - L. : I.B.Tauris, 2006. - 351 p.

27. Iranian Cinema. - Electronic text data. - Mode of access: http://www.persia.ru/upload/block39aistoria-iranskogo-kinematographa. - Title from screen. 
28. Muriel, A. Russia and Iran in the Great Game / A. Muriel // Journal Iranian Studies. - 2012. - № 45 (2) (march). - P. 306-308

\section{REFERENCES}

1. Abramov G. Etapy razvitiya otechestvennogo fotoapparatostroeniya [Stages of Camera Construction Development in Russia]. URL: http:// photohistory.ru/1207248166951435.html.

2. Ananyich B.V. Bankirskie doma v Rossii. Ocherki po istorii chastnogo predprinimatelstva [Bankers' Houses in Russia. Essays on the History of Private Entrepreneurship]. Saint Petersburg, SanktPeterburgskiy Institut istorii RAN, 2006. 295 p.

3. Ananyich B.V. Rossiyskoe samoderzhavie $i$ vyvoz kapitalov 1885-1914. Po materialam Uchetnossudnogo banka Persii [Russian Autocracy and Capital Challenge in 1885-1914. Based on Materials of the Loan and Account Bank of Persia]. Leningrad, Nauka Publ., 1975. 211 p.

4. Belyaev S.G. P.L. Bark i finansovaya politika Rossii 1914-1917 gg. [P.L. Bark and Financial Policy of Russia in 1914-1917]. Saint Petersburg, SPbGU Publ., 2002. 620 p.

5. Belyaev S.G. Uchetno-ssudnyy bank Persii v gody Pervoy mirovoy voyny [Loan and Account Bank of Persia During the First World War]. Rossiya $v$ XIX$X X v v$. [Russia in the $19^{\text {th }}-20^{\text {th }} \mathrm{cc}$.]. Saint Petersburg, Sankt-Peterburgskiy Filial Instituta Rossiyskoy istorii RAN, 1998, pp. 276-285.

6. Vestnik finansov, promyshlennosti i torgovli [Bulletin of Finance, Industryand Trade]. Saint Petersburg, Ministerstvo finansov, 1903, vol. IV, no. 48. 308 p.

7. Guryev B.M. Poezdka v Tavriz: Uchetnossudnyy bank Persii [Trip to Tavriz: Loan and Account Bank of Persia]. Biblioteka drevnikh rukopisei. Razdel VII [Library of Ancient Manuscripts. Section 7]. URL: http:/www./drevlit.ru/iran/XX/1900-920/GurjevB.M./ text10 eb8/php.

8. Dela o zagranichnykh denezhnykh operatsiyakh. Komitet finansov (1813-1918) [Cases on Foreign Money Transactions. Finance Committee (18131918)]. Rossiyskiy gosudarstvennyy istoricheskiy arkhiv [Russian State Historical Archive], F. 563, Op. 2, D. 231, Ed. khr. 1035.

9. Dela Uchetno-ssudnogo banka Persii (19001921) [Cases of Loan and Account Bank of Persia (19001921)]. Arkhiv vneshney politiki Rossiyskoy imperii [The Archive of Foreign Politics of Russian Empire]. F. "Persian Table", Op. 400, D. 916.

10. Dela Uchetno-ssudnogo banka Persii (19001921) [Cases of Loan and Account Bank of Persia (19001921)]. Arkhiv vneshney politiki Rossiyskoy imperii [The Archive of Foreign Politics of Russian Empire]. F. “Central Asian Table”, Op. 485, D. 2768, Part II.
11. Delo o dorozhnom stroitelstve v Persii. Departament zheleznykh dorog v Rossii MF (1902-1903) [The Case on Road Construction in Persia. Department of Railways in Russian Ministry of Finance (19021903)]. Rossiyskiy gosudarstvennyy istoricheskiy arkhiv [Russian State Historical Archive], F. 268, Op. 3, D. 3875, Ed. khr. 1036.

12. Delo o nagrazhdenii ryada persidskikh poddanykh russkimi ordenami i medalyami. Uchetnossudnyy bank Persii MF (1904-1915) [The Case on Awarding a Number of Persian Subjects with Russian Orders and Medals. Loan and Account Bank of Persia, Ministry of Finance (1904-1915)]. Rossiyskiy gosudarstvennyy istoricheskiy arkhiv [Russian State Historical Archive], F. 600, Op. 2, D. 1460, Ed. khr. 45.

13. Delo o pokupke kinematografa. Uchetnossudnyy bank Persii MF (1904-1905) [The Case on Buying a Movie. Loan and Account Bank of Persia, Ministry of Finance (1904-1905)]. Rossiyskiy gosudarstvennyy istoricheskiy arkhiv [Russian State Historical Archive], F. 600, Op. 4, D. 33, Ed. khr. 150.

14. Zaslavskaya I. Bratya Polyakovy kommersanty, dvoryane, evrei [Brothers Polyakovs Merchants, Noblemen, Jews]. Zametki po evreyskoi istorii, 2011, no. 10 (145). URL: http://www.berkovichzametki.com/November/2011.

15. Lavrushin O.N., ed. Rossiyskaya bankovskaya entsiklopediya (RBE) [Russian Banking Encyclopaedia]. Moscow, ETA Publ., 1995. 552 p.

16. Rukavitsin I.A. Uchetno-ssudnyy bank Persii kak chast russkoy politiki na Vostoke [Loan and Account Bank of Persia as a Part of Russian Politics in the East]. Filokratiya, 2012, no. 2 (27). URL: http:// www.oldbank.info.

17. Serkov S.R. Orden Svyatoy Anny. Orden Svyatogo Stanislava [Order of St. Anne. Order of St. Stanislaus]. Voenno-istoricheskiy zhurnal, 1990, no. 5. URL: http://www.soldat/ru/spravka/issuevj/vij-1990.

18. Smirnova N.I., Obraztsova T.M. Petr Lyvovich Bark (06.04.1869-16.01.1937) - chinovnik, bankir i posledniy ministr finansov Rossiyskoy imperii [Petr L. Bark (06.04.1869-16.01.1937) is a Bureaucrat, Banker and Last Minister of Finance of the Russian Empire]. URL: http://www.nlab/ru /editions/publics/751/ 3256,30.05.2008.

19. Sovetsko-iranskie otnosheniya v dogovorakh, konventsiyakh, soglasheniyakh [Soviet-Iranian Relations in Treaties, Conventions, Agreements]. Moscow, Ministerstvo inostrannykh del, 1946. 216 p.

20. Uchetno-ssudnyy bank Persii (1917-1920)

[Loan and Account Bank of Persia (1917-1920)]. Gosudarstvennyy arkhiv Rossiyskoy Federatsii [State Archive of the Russian Federation], F. R-4720, Op. 1, D. 1, Ed. khr. 1.

21. Firuz K. Borba za vliyanie v Persii. Diplomaticheskoe protivostoyanie Rossii i Anglii 


\section{ВСЕОБЩАЯ ИСТОРИЯ}

[The Struggle for Influence in Persia. Diplomatic Confrontation between Russia and England]. URL: http://state history.ru/book/www//livejournal.com.

22. Shilov D.N. Gosudarstvennye deyateli Rossiyskoy imperii 1802-1917. Bibliograficheskiy spravochnik [State Figures of the Russian Empire 18021917. Bibliographical Reference Book]. Saint Petersburg, Dmitriy Bulanin Publ., 2001. 830 p.

23. Shuf (Borey) V.A. Korrespondentsiya ob ekspeditsii v Persiyu. Russkiy bank i torgovlya $\mathrm{v}$ Tavrize [Correspondence about the Expedition to Persia. Russian Bank and Trade in Tavriz]. Novoe vremya, 1912, no. 12897. URL: http://v.shuf/narod/ru/ public3.html.
24. Entsiklopediya Tsarskogo sela [Encyclopedia of Tsarskoe Selo (Tsar's Village)]. URL: http:// www.Tsarselo.ru/yenciklopedija tsarkogo sela/nauka-i tehnika v tsarkom sele/totele,2015.

25. Andreeva E. Russia and Iran in the Great Game. Travelogues and Orientalism. London, Routlege, 2007. 288 p.

26. Homa K. State and Society in Iran. The Eclipse of the Qajars and the emergence of the Pahlavi's. London, I.B. Tauris, 2006. 351 p.

27. Iranian Cinema. URL: http://www.persia.ru// upload/block39a-istoria-iraskogo kinematogpha.

28. Muriel A. Russia and Iran in the Great Game. Journal of Iranian Studies, 2012, no. 45 (2), pp. 306-308.

\section{Information about the Author}

Irina K. Pavlova, Candidate of Sciences (History), Associate Professor, Department of History, Philosophies and Cultural Studies, Saint Petersburg State University of Industrial Technologies and Design, Ivana Chernykh St., 4, 198095 Saint Petersburg, Russian Federation, pik_2003@mail.ru, http://orcid.org/ 0000-02-4677-2765.

\section{Информация об авторе}

Ирина Константиновна Павлова, кандидат исторических наук, доцент кафедры истории, философии и культурологии, Санкт-Петербургский государственный университет промышленных технологий и дизайна, ул. Ивана Черных, 4, 198095 г. Санкт-Петербург, Российская Федерация, pik_2003@mail.ru, http://orcid.org/0000-02-4677-2765. 